Post peer review version of Jenny Edkins and Maja Zehfuss, "Generalising the International", Review of International Studies, vol. 31, no. 3 (2005), pp. 451-472. (ISSN 0260-2105 print/ISSN 1469-9044 online)

\title{
Generalising the International
}

\author{
Jenny Edkins and Maja Zehfuss
}

\section{Generalising the International}

\begin{abstract}
:
Ironically, since September $11^{\text {th }}$, world politics seems to have taken a turn towards certainty. This paper is an intervention that demonstrates how the illusion of the sovereign state in an insecure and anarchic international system is sustained and how it might be challenged. It does so through a Derridean analysis of Hedley Bull's The Anarchical Society. The paper examines how international relations thinking works; it teases out the implications of our reading of Bull's work and proposes that what we call generalising the international could lead to an alternative analysis of world politics, one that retains an openness to the future to come and to politics.
\end{abstract}




\section{Generalising the International ${ }^{1}$}

The fact is that while there is a great desire to know what the future of world politics will bring, and also to know how we should behave in it, we have to grope about in the dark with respect to one as much as to the other. It is better to recognise that we are in darkness than to pretend that we can see the light.

-Hedley Bull ${ }^{2}$

Ironically, since the destruction of the towers of the World Trade Center buildings in New York in September 2001, world politics seems to have taken a turn towards certainty. This may seem a paradoxical thing to say, but despite an emphasis on insecurity in current discourse, the openness evident in debates that took place after the end of the cold war about the nature of world order seems to be over. It appears we are no longer in a position where we do not know what 'new world order' we have: the period since 1989 is now often described more as an interregnum between two 'wars' than the beginning of something different. A new framework has been mapped out and a new course of action charted by the administration of the world's remaining 'hyperpuissance': the United States of America. Although that framework claims for its foundation the impossibility of secure knowledge, calling instead for recognition of the extent of what cannot be known, ${ }^{3}$ it nevertheless points with certainty to a particular interpretation of the world in Manichean or black and white terms - "Either you are with us, or you are with the terrorists" administration claims for itself the mandate to decide such things, rejecting debate and engagement in favour of assertion. Although the world appears to be full of dangers and attention is focussed on 'insecurity', paradoxically in one sense 'security' has returned: we know who the enemy is. Of course, we don't know who the enemy is in the sense of which individuals are the terrorists, but we do apparently know that the enemy is 'the terrorists'.

Despite the new certainty this way of thinking seems to lead to at least one dilemma: it does not seem to be possible to have both security and freedom. The US administration's

\footnotetext{
${ }^{1}$ Earlier versions of this paper were presented at "Constituting Communities - Political Solutions to Cultural Difference in Europe," an International Conference convened by the Danish Research Group on Cultural Encounters, Copenhagen, 23-25 October 2003 and at the British International Studies Association annual conference, Birmingham, 15-17 December 2003. Thanks to Vivienne Jabri, Monika KirloskarSteinbach, Peter Lawler, Margaret Moore, Tore Vincents Olsen, Noel Parker, Vanessa Pupavać, Nick Vaughan-Williams, Ole Wæver and other participants at these meetings for their contributions and to David Campbell, Stuart Elden, Hidemi Suganami and Julian Reid for their comments on a written draft.

${ }^{2}$ Hedley Bull, The Anarchical Society: A Study of Order in World Politics, 2nd ed. (London: Macmillan, 1995), p. 308.

${ }^{3}$ It could be argued, however, that by the act of specifying that there are 'unknown unknowns' as this thinking does, it attempts to assume knowledge of and hence control over what 'we don't know we don't know' as well as over what 'we know we don't know'. Donald Rumsfeld, NATO Press Conference, 06/06/02; Secretary Donald Rumsfeld in United States Department of Defense, Testimony of U.S. Secretary of Defense Donald Rumsfeld before the House Armed Services Committee regarding Iraq (Transcript), $18 / 09 / 02$.

${ }^{4}$ George W. Bush, Address to a Joint Session of Congress and the American People, Office of the Press Secretary, The White House, September 20, 2001.
} 
considered response to what (as they saw it) had happened on September $11^{\text {th }}$ was both obvious and self-contradictory. On the one hand they argued that the "enduring vulnerability" demonstrated so plainly was not going to disappear; on the other, that what was needed was "a comprehensive plan . . . to enhance our protection and reduce our vulnerability to terrorist attacks." " A National Strategy for Homeland Security was published that set out to "ensure the security of our people and preserve our democratic way of life," whilst at the same time acknowledging that "our population and way of life are the source of our Nation's greatest strength, but also a source of inherent vulnerability." In a similar way, the so-called war on terror was admitted to be a doubleedged sword, such that "even as we experience success in the war on terrorism, the antipathy of our enemies may well be increasing and new enemies may emerge." 7 The inherent dilemmas appear even more plainly further on in the strategy document, when details of what is proposed are set out. The very way that terrorists operate is said to make it almost impossible to counter their activities. They are "opportunistic" and "exploit whatever vulnerabilities we leave exposed." This means that if we succeed in protecting one aspect of life, they will turn to another. For example, "increasing the security of a particular type of target, such as aircraft or buildings, makes it more likely that terrorists will seek a different target." This is clearly but perhaps inadequately described by the document as producing "a formidable challenge." We are nevertheless assured that the federal government will work alongside other entities "to provide America the security it requires." 8

Susan Buck-Morss points out how the logic of political discourse has changed from one based on epistemological claims ("Because the US does not violate human rights, it is a civilised nation") to ontological ones ("Because the US is a civilised nation, it does not violate human rights"). ${ }^{9}$ In other words, once the US is defined as 'the land of the free'once that is what the US $i s$ - then anything it does, in the name of security, for example, cannot be a violation of human rights. In other words, as Buck-Morss puts it, this leads to a situation where "the post September 11 brave-new-world of surveillance... because it is being constructed by the 'free' world...is supposedly not a violation of freedom."10 However, despite the confidence with which the administration asserts its solution, the logical dilemma remains inescapable. If it is concluded that vulnerability to "terrorist attacks" arises because of "the freedoms we hold dear," the reduction of vulnerability is bound to involve a trade-off with those very rights and freedoms. ${ }^{11}$ The actions of the federal government led to considerable but largely ineffectual opposition from rights groups who did indeed see the proposed legislation and practices of detention as a

\footnotetext{
${ }^{5}$ George W. Bush, Letter to 'My fellow Americans', July 16, 2002 (accompanies Office of Homeland Security, National Strategy for Homeland Security, July 2002).

${ }^{6}$ Office of Homeland Security, National Strategy for Homeland Security, July 2002, p. 7.

${ }^{7}$ National Strategy for Homeland Security, p. 7.

${ }^{8}$ National Strategy for Homeland Security, p. 29. In addition, as Jean Baudrillard points out, "all the means of death and destruction can do nothing against an enemy who has already turned his death into a counterstrike weapon." The Spirit of Terrorism (London: Verso, 2002), p. 16.

${ }^{9}$ Susan Buck-Morss, Thinking Past Terror: Islamism and Critical Theory on the Left (London: Verso, 2003), p. 64.

${ }^{10}$ Buck-Morss, Thinking Past Terror, p. 71.

${ }^{11}$ Bush, Letter, pp. 1-2.
} 
disproportionate infringement of civil liberties. ${ }^{12}$ The restriction of civil rights in the name of fighting terrorism has been strongly contested, but the debate has been largely framed around the dichotomy between action and inaction, aiming for security and living with insecurity. It is a debate that takes for granted that security within a bounded community is to be valued. ${ }^{13}$

Although since September $11^{\text {th }}$ there has been a renewed, if perhaps flawed, sense of purpose and certainty about international politics, on the day itself the first response of the US administration to what they immediately read as an attack on America was one of chaos and confusion. The images of that day seemed testimony to the impotence of authority, and the lack of a co-ordinated response was obvious and humiliating. Leading figures went to ground in a plan rehearsed for a nuclear scenario, failing to reappear until many hours later. The apparent vulnerability of the United States to terrorist attack, clear to everyone watching, became even more obvious later when it was discovered that the methods used by the attackers had been simple and entirely unsophisticated. However, the leaders swiftly re-emerged and the events that had taken place were inscribed as an attack, not on three office buildings in New York and Washington but on the American nation and state. The authority of the state, its basis in 'freedom' and the distinction between domestic space and the outside was re-established. In fact, President George W. Bush's first reaction was to call for a moment's silence in memory of those who were to become victims and ask for God's blessing on America. ${ }^{14}$ Since then the image of September $11^{\text {th }}$ and the need to remember the 'heroes' of that day has been continually evoked to justify the administration's policies. ${ }^{15}$

There have been a number of voices raised that have argued that rather than moving to reinstate previous forms of authority, the events of 2001 provided an opportunity for a fundamental rethinking of politics and political action, both within international relations scholarship $^{16}$ and among academics more broadly. One such voice has been that of Judith Butler. She argues that the fact that "US boundaries were breached, that an unbearable vulnerability was exposed, that a terrible toll on human life was taken, were, and are, cause for fear and for mourning; they are also instigations for patient political

\footnotetext{
${ }^{12}$ See, for example, David Cole, "Enemy Aliens and American Freedoms", The Nation, 23 September 2002, pp. 20-26.

${ }^{13}$ Scholars have of course been debating the value of the search for security in a necessarily insecure world for some time. Barry Buzan, Jaap de Wilde, and Ole Waever, The New Security Studies (Boulder, Colorado: Lynne Rienner, 1997); Michael Dillon,. The Politics of Security (London: Routledge, 1996); Jenny Edkins, "After the Subject of International Security", in Alan Finlayson and Jeremy Valentine (eds.), Politics and Poststructuralism (Edinburgh: Edinburgh University Press, 2001), pp. 87-110; K. M. Fierke, "Meaning, Method and Practice: Assessing the Changing Security Agenda", in Stephanie Lawson (ed.), The New Agenda for International Politics: From Polarization to Globalization in World Politics (London: Polity, 2001), pp. 128-144; Keith Krause and Michael C. Williams (eds.), Critical Security Studies (Boulder, Colorado: Lynne Rienner, 1996).

${ }^{14}$ Jenny Edkins, "The Rush to Memory and the Rhetoric of War", Journal of Political and Military Sociology vol. 31, no. 2 (2003), pp. 231-51.

${ }^{15}$ Maja Zehfuss, "Forget September 11", Third World Quarterly: Journal of Emerging Areas, vol. 24, no. 3 (2003), pp. 513-528.

${ }^{16}$ See for example, Ken Booth and Tim Dunne (eds.), Worlds in Collision: Terror and the Future of Global Order (London: Palgrave Macmillan, 2002).
} 
reflection." 17 The "United States was missing an opportunity to redefine itself as part of the global community when, instead, it heightened nationalist discourse, extended surveillance mechanisms, suspended constitutional rights, and developed forms of explicit and implicit censorship." 18 What Butler calls for instead is reflection on what the experience of vulnerability can teach us about forms of political community that are not dependent on the sovereign state and its exclusions but that acknowledge "inevitable interdependency... as the basis for global political community." She sees vulnerability as something that humans share, and argues that "to foreclose that vulnerability, to banish it, to make ourselves secure at the expense of every other human consideration is to eradicate one of the most important resources from which we must take our bearings and find our way."19 Mary Midgley, commenting on Butler's work, reminds us that the notion of invulnerability that was shattered on September 11th was in any case "part of a huge structure of illusion, a structure that centres on the idea of the US as a fortress civilisation, isolated in a sea of evil which it has somehow to subdue." 20 The blow that the destruction of the twin towers dealt to that illusion provided an opportunity "for a deep reshaping of that whole ideology, a return to the reality of a complex world.",21

What we are attempting in this paper is an intervention that demonstrates how the illusion of the sovereign state in an insecure and anarchic international system is sustained and how it might be challenged. It seems to us that this has become important in the present circumstances. The focus on security and the dilemma of security versus freedom that is set out in debates immediately after September $11^{\text {th }}$ presents an apparent choice as the focus for dissent, while concealing the extent to which thinking is thereby confined to a specific agenda. Our argument will be that this approach relies on a particular picture of the political world that has been reflected within the discipline of international relations, a picture of a world of sovereign states. We have a responsibility as scholars; we are not insulated from the policy world. What we discuss may not, and indeed does not, have a direct impact on what happens in the policy world, this is clear, but our writings and our teaching do have an input in terms of the creation and reproduction of pictures of the world that inform policy and set the contours of policy debates. ${ }^{22}$ Moreover, the discipline within which we are situated is one which depends itself on a particular view of the world - a view that sees the international as a realm of politics distinct from the domestic - the same view of the world as the one that underpins thinking on security and defence in the US administrations. ${ }^{23}$ In this paper then we develop an analysis of the

\footnotetext{
${ }^{17}$ Judith Butler, Precarious Life: The Powers of Mourning and Violence (London: Verso, 2004), p. xi.

${ }^{18}$ Butler, Precarious Life, p. xi.

${ }^{19}$ Butler, Precarious Life, p. 30.

${ }^{20}$ Mary Midgley, "Counting the Cost of Revenge", The Guardian (London), Saturday Review, 5 June 2004.

${ }^{21}$ Midgley, "Counting the Cost."

${ }^{22}$ Steve Smith, "Singing our world into existence: International Relations theory and September $11^{\text {th, }}$, ,International Studies Quarterly, vol. 48, no. 3 (2004), pp. 499-515.

${ }^{23} \mathrm{We}$ are certainly not the first critical international relations scholars to point this out. It has been a feature of critical thinking for at least the last decade, and many people have engaged this problem in different ways. It has perhaps been most directly tackled in the work of Richard K. Ashley, Richard Falk and R. B. J. Walker. See, for example Richard K. Ashley, "Living on Border Lines: Man, Poststructuralism and War", in James Der Derian and Michael J. Shapiro (eds.), International/Intertextual Relations, (New York: Lexington Books, 1989), pp.259-321; R. B. J. Walker, Inside/Outside: International Relations as Political Theory (Cambridge: Cambridge University Press, 1993); Richard Falk, Lester Edwin
} 
ways in which thinking in terms of international relations and a system of states forecloses certain possibilities from the start, and how it might look to think politics and the international differently.

Our chosen point of intervention is to examine how international relations thinking works; by showing how this thinking operates, and how it relies on certain analytical moves and particular categorisations and dichotomies, we hope to demonstrate that it is not the only way that world politics could be thought. Identifying the underpinnings of existing frameworks is an important preliminary before new thinking can be fully effective and is itself a first move in dislodging these underpinnings. We have chosen to base our analysis on the work of Hedley Bull. This is for several reasons. First, Bull acknowledges in the preface to The Anarchical Society that he owes a profound debt to Martin Wight, "who first demonstrated that International Relations could be made a subject." 24 We take Bull then as an example of someone who was attempting to establish 'International Relations' as an academic discipline, and thus as an appropriate starting point in our attempt to 'disestablish' it. Second, Bull provides an example of a theorist of international relations who sets out his position in a way that makes the underlying logic clear and thus available for analysis. He is well aware of the way in which it is necessary to neglect certain aspects of world politics in order to produce 'International Relations' and is quite explicit in general about the moves he makes in order to do this. Bull's logic involves the types of impossible dilemmas and contradictions that we have located in current thinking about terrorism and vulnerability. In particular he discusses the relationship between order and justice, as two fundamental principles of international relations, and then sets aside the question of justice in order to focus on order. This is the third reason for focussing on his work. There are important parallels to be made between 'order' as it appears in Bull and 'security' in debates after September $11^{\text {th }}$. We tease out the implications of our reading of Bull's Anarchical Society and propose that what we call generalising the international could lead to an alternative analysis of world politics, one that did not replace politics with security or justice with order.

It is important to note, before we begin our reading of Bull's work, that what we are attempting here is distinct from approaches that focus on what authors are trying to do and therefore on what they represent as the main argument. Our analysis, in contrast, reads between the lines. Such an approach involves a very meticulous reading, and it demands a detailed study of one author and one work rather than a more wide-ranging discussion of, for example, a series of international relations scholars. In order to make a clear argument authors invariably exclude or defer for later consideration aspects of the issue under consideration that they see as marginal. Our reading seeks to tease out the way in which these deferrals turn out to be central to the argument. In other words, we explore how the 'main' argument is always already under threat from that which is

J. Ruiz and R. B. J. Walker (eds.), Reframing the International (New York: Routledge, 2002). Although these various interventions and the many we have not listed have had considerable impact, the argument has by no means been won. It seems to us that there is room for a further intervention, one that takes a different approach, especially when an altered interpretation of the world is in the process of becoming entrenched in public discourse.

${ }^{24}$ Bull, Anarchical Society, p. xiii. 
excluded as insignificant. This means that our reading is not concerned with what Bull wants to say but with the implications of what he does say. Highlighting what is dismissed as unimportant is a rhetorical move that makes it possible to politically intervene in the discourse; it takes its cue from within the discourse but shifts the perspective.

\section{Order}

In his study The Anarchical Society, Hedley Bull is concerned with the issue of order in world politics. He starts his consideration of order by discussing it as a general problem. He talks, for example, about how one may order books on a shelf before proceeding to look at it as a concern in social life. According to Bull, "To say of a number of things that together they display order is, in the simplest and most general sense of the term, to say that they are related to one another according to some pattern, that their relationship is not purely haphazard but contains some discernible principle." ${ }^{25}$ Order is opposed to disorder. A class of objects may be ordered in different ways. Books, for example, could be arranged alphabetically by author, but whilst this would certainly be order in some sense it would be unhelpful if we were looking for a book on a particular subject, rather than by a specific author. Thus, order and purpose are in some fundamental way connected. This point takes on significance when Bull considers order in social life. Order in social life refers to "a pattern of human activity that sustains elementary, primary or universal goals". ${ }^{26}$ Bull proceeds to postulate that there are three elementary or primary goals that all societies recognise and seek to promote:

First, all societies seek to ensure that life will be in some measure secure against violence resulting in death or bodily harm. Second, all societies seek to ensure that promises, once made, will be kept, or that agreements, once undertaken, will be carried out. Third, all societies pursue the goal of ensuring that the possession of things will remain stable to some degree, and will not be subject to challenges that are constant and without limit. ${ }^{27}$

It is useful to examine further what precisely Bull is doing. What he says is:

The order which men look for in social life is not any pattern or regularity in the relations of human individuals or groups, but a pattern that leads to a particular result, an arrangement of social life such that it promotes certain goals or values. $^{28}$

There are two things to note. First social life has to be purposive; it has to have some purpose outside that of mere co-existence. Intention is central. Societies are defined as

\footnotetext{
${ }^{25}$ Bull, Anarchical Society, p. 3. It is interesting of course that Bull does not question in what sense the objects to be ordered can be said to 'exist' or form part of a 'class' prior to their ordering. In other words, he does not examine the possibility of radical relationality: he does not consider, for example, whether an object might only become what we call 'a book' by virtue of its positioning on a shelf alongside other books.

${ }^{26}$ Bull, Anarchical Society, p. 4.

${ }^{27}$ Bull, Anarchical Society, p. 4.

${ }^{28}$ Bull, Anarchical Society, p. 3f (our emphasis).
} 
groups which promote certain basic values, values that Bull argues all societies, in order to warrant the definition 'society', must promote. Second Bull excludes or puts to one side forms of order that do not lead to a particular result. A pattern that fails to promote the goals or values of a particular society does not count as order for Bull. In other words, Bull in his study of order is not only excluding certain forms of order but he is doing so on the grounds of intention.

This reminds us of the way in which, in his exposition of speech act theory, J. L. Austin puts to one side or excludes as unimportant to his study speech acts which are not serious but rather what he calls 'parasitic' on normal usage: occasions when words such as 'I pronounce you man and wife' are uttered in the course of a theatrical drama for example. 'Performatives' are speech acts that produce effects rather than just describing things; Austin wants to look only at 'successful' performatives, those that produce the effects they intend. Intention is central here, as it was with societies and their goals. Derrida, in his analysis of Austin's work, asks whether what Austin excludes is not in fact the very thing "without which there would not even be a 'successful' performative?"29 He argues that the risk of failure of a speech act is the very condition of possibility of its success in the first place: "this risk [is] its internal and positive condition of possibility." 30

We have already noted that intention is central to Bull's exclusions, as it is to Austin's. Both shelter, in Derrida's words, "the teleological lure of consciousness." 31 Both in other words assume that there is a fully self-conscious intentional actor present behind the action. This is problematic, Derrida argues, in the case of the speaking individual, who cannot be assumed to be fully in control of their speech. It is arguably even more problematic in the case of Bull's societies. Bull wants to argue for certain goals that all societies recognise and promote. However, "conscious intention" is not "totally present and immediately transparent to itself and others" $" 32$ as we recognise: it is not possible to be certain about the intention that motivates behaviour either of individuals or of states. Bull, like Austin, attempts to exclude order that does not 'succeed', forms of order that do not lead "to an arrangement of social life such that it promotes certain goals and values." 33 However, much of what constitutes society or what Bull calls 'social life' takes place because of the very disagreements and debates about goals and purposes that he wants to claim are already decided. It is a condition of possibility of social and political life that there are differences and disagreements between people, and that neither people's intentions nor their thoughts are transparently communicable. The appearance of order or effects of order in social life, like the effects of speech in Austin's analysis, "do not exclude what is generally opposed to them, term by term; on the contrary, they presuppose it, in an asymmetrical way, as the general space of their possibility." "34 In other words, to return to Bull and his definition of order, what we are then obliged to

\footnotetext{
${ }^{29}$ Derrida, Jacques, "Signature Event Context”, trans. Samuel Weber and Jeffrey Mehlman, in Jacques Derrida, Limited Inc (Evanston, Illinois: Northwestern University Press, 1988), p. 17.

${ }^{30}$ Derrida, "Signature Event Context", p. 17.

${ }^{31}$ Derrida, "Signature Event Context", p. 18.

${ }^{32}$ Derrida, "Signature Event Context", p. 18.

${ }^{33}$ Bull, Anarchical Society, p. $3 \mathrm{f}$.

${ }^{34}$ Derrida, "Signature Event Context", p. 19.
} 
admit is that the possibility of order (of the type Bull wants to discuss) relies on the very possibility of disorder that he wants to dismiss.

It is the possibility of disorder that enables him to recognise order in the first place. It is because of the possibility or even prevalence of behaviour that may be patterned - such as that of sovereign states in "circumstances of war and crisis" order is an issue of concern. The point of order is to keep disorder in check; disorder is always already there when he speaks of order. Accordingly, the reason that Bull wants to study order in world politics is precisely because the "element of disorder looms as large or larger in world politics than the element of order". ${ }^{36}$ Disorder here, of course, means any form of behaviour that does not sustain what Bull has identified as the primary goals.

The relationship in Bull's thinking between order and value is an interesting one. As we have seen order is defined in terms of values; Bull also discusses with some unease the question of the value of order itself. Whilst he claims that "order...is defined as an actual or possible situation or state of affairs, not as a value, goal or objective", ${ }^{37}$ in the next paragraph he says that, "of course" and "in common with most men," he attaches value to order. Moreover, order in world politics is a "desirable objective" 38 and this makes it worthy of study. Bull is fully aware that there are other, competing objectives such as, most importantly, justice. Though he will discuss some aspects of justice in world politics, in as far as they relate to his subject of order, he sets aside this concern to make possible, he argues, his study of order. ${ }^{39}$ The question of justice is in other words deferred to make possible the study of order. This deferral is crucial. The postponement of the consideration of justice is not innocent, but provides the ground for an analysis that prioritises order.

It could be said that security, very much like order for Bull, is to be automatically valued. It is "a desirable objective" and one not generally questioned. ${ }^{40}$ The literature on security "does not ask the question of security as such. It invokes security as a ground and seeks largely to specify what security is; how security might be attained; and which are the most basic, effective, or cost-effective means of doing so." 41 Questions about the value of security are not asked; they are "displaced by the technically biased, narrowly framed question of what it takes to achieve security." 42 As we saw in the National Strategy for Homeland Security, there are recognised to be other, potentially incompatible objectives-retaining the freedoms that characterise American identity, for example. These are recognised when the document states that "the US Government has no higher purpose than to ensure the security of our people and preserve our democratic way of

\footnotetext{
${ }^{35}$ Bull, Anarchical Society, p. 3.

${ }^{36}$ Bull, Anarchical Society, p. xv.

${ }^{37}$ Bull, Anarchical Society, p. xvi.

${ }^{38}$ Bull, Anarchical Society, p. xvi.

${ }^{39}$ Bull, Anarchical Society, p. xvi. Bull does, of course, examine the pursuit of economic and social justice in Part III of Anarchical Society.

${ }^{40}$ Bull, Anarchical Society, p. xvi.

${ }^{41}$ Dillon, The Politics of Security, p. 18.

${ }^{42}$ James Der Derian, "The Value of Security: Hobbes, Marx, Nietzsche, and Baudrillard", in Ronnie D.

Lipschutz (ed.), On Security (New York: Columbia University Press, 1995), pp. 24-45.
} 
life."43 However, the second part of this purpose disappears in the letter from the President that accompanies the document, where we find the unqualified statement that "the US government has no more important mission than protecting the homeland from future terrorist attacks." 44 Other concerns are set to one side to focus on how to achieve security, in much the same way as Bull sets aside the concern for justice to study order.

Bull's writing does not allow for any disagreement as to what the fundamental goals of a society should be, though he identifies them clearly. Each society is assumed to be agreed on a set of basic goals, and surprisingly, to share them with other societies. Similarly, discussions of security generally serve to sideline political differences as to the goals of security. In the discussion of Homeland Security, goals are explicitly identified. "The American people and way of life" are "our highest protective priority." 45 This "way of life" involves "five key elements: democracy, liberties, security, economics, and culture."46 However, the document is presented as "a comprehensive and shared vision of how best to achieve" these goals, and discussion seems to have been limited to means, not ends. ${ }^{47}$

\section{Justice}

Although justice was originally put to one side to think about order, order is closely related to justice in Bull's thinking. Where he does consider justice, he does so only insofar as it is "essential to the treatment of order." 48 Existing order on the one hand can be seen to provide the basis for justice and on the other to be inimical to justice. According to Bull, "It is obvious that the existing framework of international order fails to satisfy some of the most deeply felt and powerfully supported of these aspirations for justice." 49 He refers here to claims that the states of the Third World are concerned to achieve justice in the world, "even at the price of disorder", 50 whereas the Western states are interested in preserving the current international order. The reason that justice is, as it were, a danger to order is the unequal distribution of wealth across states. "Demands for world justice are therefore demands for the transformation of the system and society of states, and are inherently revolutionary." between order and justice, the relationship is more complex. Bull says that "It is true that justice, in any of its forms, is realisable only in a context of order; it is only if there is a pattern of social activity in which elementary or primary goals of social life are in some way provided for, that advanced or secondary goals can be secured." ${ }^{52}$ In other words, the pursuit of the goals of justice presupposes the existence of a society in the first place. Thus, Bull asserts, on the one hand, that order is the very basis for justice and, on the other, that the "framework of international order is inhospitable also to demands for

\footnotetext{
${ }^{43}$ Homeland Security, p. 7 (emphasis added).

${ }^{44}$ Bush, Letter, p. 1.

${ }^{45}$ Homeland Security, p. 7.

${ }^{46}$ Homeland Security, p. 8.

${ }^{47}$ Bush, Letter, p. 1.

${ }^{48}$ Bull, Anarchical Society, p. xvi.

${ }^{49}$ Bull, Anarchical Society, p. 83.

${ }^{50}$ Bull, Anarchical Society, p. 74.

${ }^{51}$ Bull, Anarchical Society, p. 84.

${ }^{52}$ Bull, Anarchical Society, p. 83.
} 
human justice" ${ }^{53}$ Justice cannot be deferred from the consideration of order, since, among other things, justice, in Bull's view, requires order. In other words, these two things cannot be considered separately because they are both implicated in each other. It is thus only inasmuch as there is an international society that we may enjoy justice in the international context. In other words, justice is a supplement to order, something that may exist only as an add-on where there is order already. Order is "prior to other goals, such as that of justice." ${ }^{54}$

Bull ventures a further reason for dismissing justice from his scholarly inquiry. In his view, justice, unlike order, "is a term which can ultimately be given only some kind of private or subjective definition." shown, order, with its inextricable relationship to purpose, is in fact also subjective. It is only when we recognise a purpose that we may call a pattern order. Moreover, Bull is not interested in order merely as a "condition or state of affairs" but as something that is "very generally regarded as a value." cannot be defined a priori, according to a set of criteria.

Though Bull sees justice as only possible where there is order, his inability to define justice because it is somehow subjective points to the need to think about justice other than in the context of general distinctions and principles. In Bull's view, ideas about justice "belong to the class of moral ideas, ideas which treat human actions as right in themselves and not merely as a means to an end, as categorically and not merely hypothetically imperative. ${ }^{, 57}$ It is useful here to return to Derrida. Justice in the Derridean sense "always addresses itself to singularity, to the singularity of the other, despite or even because it pretends to universality." ${ }^{, 58}$ The exercise of justice must therefore necessarily involve a decision, a "fresh judgment." 59 Such a decision must go through what Derrida calls the undecidable: "The undecidable is not merely the oscillation between two decisions; it is the experience of that which, though heterogeneous, foreign to the order of the calculable and the rule, is still obliged ... to give itself up to the impossible decision, while taking account of the law and rules." ${ }^{\circ 60}$ The undecidable is an aporia, a "'non-way', you cannot find your way: a-poria means that you cannot walk further, it's a blocked way, there is no way." when it comes to justice we are confronted with imperative demands that may not be reconciled; there is no rule and no knowledge that tells us what is the just decision. This

\footnotetext{
${ }^{53}$ Bull, Anarchical Society, p. 85.

${ }^{54}$ Bull, Anarchical Society, p. 93.

${ }^{55}$ Bull, Anarchical Society, p. 75.

${ }^{56}$ Bull, Anarchical Society, p. 74.

${ }_{58}^{57}$ Bull, Anarchical Society, p. 75.

${ }^{58}$ Jacques Derrida, "Force of Law: The 'Mystical Foundation of Authority"”, in David Gray Carlson, Drucilla Cornell, Michel Rosenfeld (eds.), Deconstruction and the possibility of justice (Routledge:

London, 1992), p. 20.

${ }^{59}$ Derrida, "Force of Law", p. 21.

${ }^{60}$ Derrida, "Force of Law", p. 24.

${ }^{61}$ Jacques Derrida, Deconstruction Engaged. The Sydney Seminars, Edited by Paul Patton and Terry Smith (Sydney: Power Publications, 2001), p. 63.
} 
experience of the aporia is, according to Derrida, fundamental to the possibility of politics:

I will even venture to say that ethics, politics, and responsibility, if there are any, will only ever have begun with the experience and experiment of aporia. When the path is clear and given, when a certain knowledge opens up the way in advance, the decision is already made, it might as well be said that there is none to make: irresponsibly, and in good conscience, one simply applies or implements a program. [...] The condition of possibility of this thing called responsibility is a certain experience and experiment of the possibility of the impossible: the testing of the aporia from which one may invent the only possible invention, the impossible invention. ${ }^{62}$

Thus, when Bull excludes contestation over the basic goals of society and defers the consideration of justice to concentrate on order he is defining away politics. Politics, according to Derrida, comes into play precisely when things are not ordered neatly according to rules, when we are faced with options that are both contradictory and imperative, and knowledge therefore fails us. For example, the apparent choice between security and freedom actually requires a political decision. Between the best knowledge that we may have and the decision there always remains a gap. As Derrida explains, "it is necessary to know the most and the best possible, but between the widest, the most refined, the most necessary knowledge, and the responsible decision, an abyss remains, and must remain."63 Making a decision is, in other words, inevitably marked by uncertainty. It is this uncertainty that Bull suppresses, much as the declarations by the US administration to ensure US security suppress the impossibility of knowing even what the threats are.

\section{Domesticating the international}

So far, in considering Bull's analysis of order, we have teased out the way in which distinctions work to provide a particular context within which the argument presented in The Anarchical Society ostensibly makes sense. Bull, as we have seen, defers the consideration of justice in favour of what he takes to be his main subject: order. Thus the question of justice is excluded from the discussion of order as alien, external. Having thus dismissed the question of justice for the time being, Bull starts his consideration of order, after some general points, with a discussion of order in domestic societies. Domestic order is set out as a clear and in fact the paradigmatic case. Order in social life "promotes certain goals and values" and these are easily identifiable in the case of domestic society: security from violence; the keeping of promises, especially contracts; and the stability of possessions. ${ }^{64}$ Bull asserts these as unproblematic. He assumes not only that on the whole members of society would agree with the promotion of these goals (murderers, fraudsters, thieves, and revolutionaries must here be seen as excluded on

\footnotetext{
62 Jacques Derrida, The Other Heading. Reflections on Today's Europe, translated by Pascale-Anne Brault and Michael B. Naas (Bloomington and Indianapolis: Indiana University Press 1992), p. 41.

${ }^{63}$ Jacques Derrida, On Cosmopolitanism and Forgiveness, translated by Mark Dooley and Michael Hughes (London and New York: Routledge, 2001), p. 54.

${ }^{64}$ Bull, Anarchical Society, p. 4.
} 
grounds of marginality) but also that these basic goals are common to all societies. It is not merely Bull's own community that would support these aims but he expects that we would find the same primary goals in every community that we might examine.

In other words, Bull has started his analysis with what it seems he regards as the easy case: order in domestic society. From there he develops his discussion of international and world order. International order refers to a "pattern of activity that sustains the elementary or primary goals of the society of states." to domestic order with states taking the role of individuals. This means that Bull comes to a definition of social order by considering order in domestic society and identifying a series of basic goals that are regarded as such in all societies that are to count for Bull as societies. When he comes to order in the international realm he postulates a society of states and repeats the definition of social order as a pattern of activity that sustains the basic goals of that society. It seems to us that it is significant that he starts with the domestic and then moves to the international.

Bull takes his understanding of domestic order as a springboard to analyse the issue of international order. Whereas domestic order is in this sense largely a description of what actually is, order in the international sphere constitutes a problem. The "element of disorder looms as large or larger in world politics than the element of order," he says. ${ }^{66}$ A chapter is devoted to asking whether order in world politics exists, a question that was not explored in relation to domestic order. Order again refers to the promotion of primary goals, which have however been amended in application to world politics: the preservation of the system and society of states itself; maintaining external sovereignty of individual states; peace; and finally the three goals established in relation to domestic society and now rendered as limitation of violence, keeping of promises and stability of possession. ${ }^{67}$ There is order in the international realm in as far as the international obeys the same kind of principles as Bull has established for the domestic. Bull's understanding of international order relies therefore on what one might call $a$ domestication of the international: the international is understood in terms of the domestic. $^{68}$

Bull quite clearly differentiates between international life, where sovereign states are not subject to a common government, and domestic life, where 'men' are. In fact anarchy, in the sense of course of the absence of rule, is for him "the central fact of international life and the starting point of theorising about it." ${ }^{, 69}$ Thus the international is associated with

\footnotetext{
${ }^{65}$ Bull, Anarchical Society, p. 8.

${ }^{66}$ Bull, Anarchical Society, p. xv.

${ }^{67}$ Bull, Anarchical Society, pp. 16-19.

${ }^{68}$ Richard Ashley traces the domestication of global life in some detail as a practice of modernist discourse and productive of the heroic figure of sovereign man (Richard Ashley, "The powers of anarchy: theory, sovereignty, and the domestication of global life", in James Der Derian (ed.) International Theory: Critical Investigations (London: Macmillan, 1995), pp. 94-128).

${ }^{69}$ Hedley Bull, "Society and Anarchy in International Relations", in H. Butterfield and M. Wight (eds.), Diplomatic Investigations (London: George Allen and Unwin, 1966), pp.35-60, reprinted in James Der Derian (ed), International Theory: Critical Investigations (London: Macmillan, 1995), pp. 75-93; p 75. Note that this step is only possible because of the way the picture works: there is only absence of rule in
} 
an absence of government, the domestic with its presence. However, he then immediately proceeds to examine and contest the view that the absence of government means there cannot be a society of states. He argues against "the domestic analogy" when it comes to insisting that international anarchy be brought to an end by a form of social contract. ${ }^{70}$ He aims to contest both the view of anarchy among states as the Hobbesian equivalent of anarchy among 'men' in a state of nature, and the view that the solution is some form of world government. In his view "the conditions for order among states are different from what they were among individual men."71 Against the two doctrines he contests, he wishes to set a third possibility: a society of sovereign states, but an anarchical society.

In terms of what we have argued about Bull's domestication of the international, this is interesting. Of course, he explicitly does not want to fully domesticate the international: he does not see the need. Order is attainable through the mechanisms of an anarchical society. However, this remains a very significant domestication. First it reiterates the distinction between international and domestic: there is no question Bull sees the two as separate realms. Second it seeks to provide order (which is found in the domestic) in the international. ${ }^{72}$ Thus, whilst Bull explicitly rejects the 'domestic analogy', his argument is implicitly based on the very possibility of domesticating the international. ${ }^{73}$

The domestication of the international, such as it is, is based on distinguishing the domestic from the international in the first place. Although Bull does not explicitly speak in terms of differentiating 'the domestic' from 'the international', he continually refers to order in 'society' and order in 'international society', for example, and treats the two as clearly distinct realms. These types of distinctions are considered in some depth in Derridean thought. Derrida argues that thought in the Western tradition is structured in general by oppositions or dichotomies such as 'domestic/international'. Other examples of this are good/evil, male/female, nature/nurture. Although both elements of the pair seem to be on an equal footing we find, on closer analysis, that one term is privileged and dominates the dichotomy.

One of the fundamental dichotomies Derrida is concerned with is that between speech and writing. Speech, he argues, has been regarded as primary and authentic whereas writing is seen as derivative, further removed from the meaning that is to be communicated. In the tradition of thought that Derrida scrutinises, writing becomes necessary only when speech is not possible, for example because the addressee of a

the international because the international and the domestic are regarded as distinct realms. We return to this later.

${ }^{70}$ Bull, "Society and Anarchy", p. 75. The domestic analogy is "the argument from the experience of individual men in domestic society to the experience of states, according to which the need of individual men to stand in awe of a common power in order to live in peace is grounds for holding that states must do the same." Bull, "Society and Anarchy", p. 75.

${ }^{71}$ Bull, "Society and Anarchy", p. 79

${ }^{72}$ Bull, "Society and Anarchy", pp. 92-93.

${ }^{73}$ In other words, despite what Ashley calls "Bull's lament", Bull's work nevertheless domesticates the international. Ashley, "The powers of anarchy”, p. 98. 
communication is absent. ${ }^{74}$ This means that "Representation regularly supplants [supplée] presence." 75 Thus speech is the best way of communicating. In speech it is possible to take into account the needs of the audience. It allows for additional elaboration. We are, in other words, happy with speech as a form of communication. It transmits meaning reliably. We should not need anything else. Writing is in a sense additional.

Analysing Ferdinand de Saussure's linguistics, Derrida claims that Saussure sees writing as "a modality of the events which can befall a language whose essence, as the facts seem to show, can remain forever uncontaminated by writing." " Speech is, in other words, primary. Writing is in that sense derivative; it is the "signifier of the first signifier, representation of the self-present voice, of the immediate, natural and direct signification of the meaning."77 Writing is thus removed one step further than speech from that which is to be communicated. Speech is therefore privileged as the more authentic, immediate form of expression. In contrast, writing is external to language, an accidental addition that we need not address in order to understand the system of language. ${ }^{78}$ Derrida points out that "writing, the letter, the sensible inscription, has always been considered by Western tradition as the body and matter external to the spirit, to breath, to speech, and to the logos."79 Saussure, for example, insists that "Languages are independent of writing. " that writing has on the spoken language, for example mispronunciations due to spelling practices.

Thus, writing, which is on the one hand considered opposite to speech and wholly external to it, on the other hand turns out to be intimately related to speech, to affect and change it. Derrida thus concludes that the "system of writing in general is not exterior to the system of language in general." representation, a sign of a sign. In fact, importantly, speech "is already in itself a form of writing." 82 This is the case because if " "writing' signifies inscription and especially the durable institution of a sign (and that is the only irreducible kernel of writing), writing in general covers the entire field of linguistic signs." 83 In other words, what Derrida refers to here as 'writing in general' or 'arche-writing' means not only writing in the narrow sense, as we commonly understand it, but any system that maybe used to record, and as a result, produce meaning.

\footnotetext{
${ }^{74}$ Derrida, "Signature Event Context", p. 5.

75 Derrida, "Signature Event Context", p. 5.

${ }^{76}$ Jacques Derrida, Of Grammatology, translated by Gayatri Chakravorty Spivak (Baltimore and London:

The Johns Hopkins University Press, 1976), p. 30.

${ }^{77}$ Derrida, Of Grammatology, p. 30.

${ }^{78}$ Derrida, Of Grammatology, p. 33.

${ }^{79}$ Derrida, Of Grammatology, p. 35.

${ }^{80}$ Quoted in Derrida, Of Grammatology, p. 41.

${ }^{81}$ Derrida, Of Grammatology, p. 43.

${ }^{82}$ Derrida, Of Grammatology, p. 46.

${ }^{83}$ Derrida, Of Grammatology, p. 44.
} 
Whereas traditionally thinkers have seen speech as the primary medium for the transmission of language and hence the most authentic way to represent meaning, on closer examination it turns out that writing is not an external and additional extra, but that in fact, on a wider understanding of what 'writing' is, speech is always already a form of writing. In other words, we started out with a dichotomy speech/writing, in which speech was privileged or valued over writing. The analysis, however, showed that writing was not only not separate from speech but that speech was dependent on writing, in other words, already itself a form of writing. The hierarchy of the terms in the dichotomy has come to be not merely overturned, but displaced. ${ }^{84}$ It is impossible to make sense of the situation in terms of the clear separation of the two terms, and inverting the hierarchical relation, although indispensable, would not be sufficient; rather it is necessary to arrive at a new understanding of 'writing in general' that incorporates what we know as 'speech'. This is crucial as otherwise the structure of thought, or the logic of the system within which we think about 'speech' and 'writing', would stay in place. Derrida deliberately chooses to reconceptualise and employ 'writing', the term that was previously less valued, rather than to perhaps invent an entirely new concept or redefine 'speech', in order to make a political intervention. The move is not logical or conceptual but rather political or rhetorical.

Speech, in our discourse on language, occupies the place of that which directly and authentically transmits meaning. It is closely related to the notion of presence. In terms of communication, it is the easy, and even ideal, case. Bull's conception of the unproblematic example of order mirrors this. As a consequence, his analysis of international order in terms of criteria established by starting from the domestic is invested with the same kind of structural flaws that Derrida teases out in his discussion of traditional understandings of speech/writing. Writing is, in a sense, set up to fail as a communication device because it is held up against an alternative, speech, that is already considered superior. Writing is understood in terms of speech, and writing, invariably, turns out to be a lesser speech: it does not allow impromptu elaboration in response to the audience, for example, whereas speech does. Communication through writing is therefore considered poorer. In a similar vein, international order can only ever be a lesser version of order because it is judged in terms of criteria derived from the alternative, domestic order. As international order is inevitably less like domestic order than domestic order it is always already precarious, endangered, and insecure. For example, whereas the primary goals are agreed in domestic order (this being, after all, the way they were defined), there is a struggle over these in the international realm. Bull cites the example of the Third World's desire to change the distribution of wealth, which can be in tension with the protection of the stability of possession. A demand that can be framed within the goals of a particular international society/system is one thing, whereas one that calls for a transformation of those goals is another. What this means is that the reason that international order, such as it is, appears to be less accomplished than domestic order is not an inherent problem with international order per se but a problem with the way in which Bull has set up the analysis. Similarly, writing turns out not to be

\footnotetext{
${ }^{84}$ On the significance of the displacement in deconstruction see Jacques Derrida, Positions, translated and annotated by Alan Bass (London: The Athlone Press, 1981), pp. 41-42.
} 
a worse form of communication but merely one that appears so because it has been analysed in terms of something else.

Derrida, as we have seen, goes on to argue that rather than think of writing as a poorer relation of speech we should think of speech as part of a generalised form of writing. It is important to recall that the reason that traditional thought ends up dismissing writing is the way in which it starts with speech as central and sufficient. In other words, if we had the option, we would always choose speech over writing. It is only if we must speak to someone who is absent, for example, that we resort to writing. Writing is thus used to compensate for the shortcomings of speech at the same time as being castigated for being less like speech than speech itself. Similarly, we might be seen as largely content with the domestic as a sphere for the realisation of the 'good life'. Bull, it seems, would be essentially happy with domestic society, were it not for the disorder in the international sphere that surely must offend his desire for order. ${ }^{85}$ It is the possibility, or rather danger, of disorder spilling into the domestic sphere that seems to be the problem. The dam between the disorder of the international and the order of the domestic is always under threat. Wars, for example, are not merely evidence of international disorder; they impact on the possibility of order in the domestic sphere. ${ }^{86}$ Following this way of thinking, the danger of such a breach of the international into the domestic was never more apparent than when two planes hit the towers of the World Trade Center.

Pushing further the analogy with Derrida's analysis of speech/writing, it becomes evident that if understanding the international in terms of the domestic, as we see it in Bull's work, creates anomalies, it is necessary to consider whether the domestic is not, in turn, already a form of the international. In other words, rather than conceptualising the international on the basis of an idealised, homogenous domestic, we might need to explore how far the domestic already bears the hallmarks of what we call the international. For example, if the agreement on the primary goals that Bull posits does not exist, if basic goals and values are always already contentious, as we habitually assume about the international sphere, then we might have to understand the domestic as what one might call, recalling Derrida's terminology, 'the international in general'. In as far as the international is not about relations between states but about a mode of existence in which all values are continuously in question the domestic may then be seen to already be a form of this 'international in general'.

\section{Generalising the international}

When we argue that the domestic should be seen as bearing the hallmarks of what we term the international, we are not, in fact, calling for what might be described as 'internationalising the domestic'-the opposite of 'domesticating the international' as in Bull's work. Rather what we are suggesting is that the domestic be seen as a form or type of an all-embracing international. In other words, we are not suggesting an inversion of the dichotomy between domestic and international such that the international

\footnotetext{
${ }^{85}$ See Bull, Anarchical Society, p. xvi.

${ }^{86}$ Bull, of course, regards war as one of the institutions of the society of states in the sense that it is a "settled pattern of behaviour shaped towards the promotion of common goals." Anarchical Society, p. 178; see also p. 88.
} 
is valued over the domestic rather than vice versa. Nor are we suggesting only that the domestic be viewed as having the characteristics of what we previously called the international. What we are proposing is that we develop a revised concept of the international, which we could call, following Derrida, a generalised international.

What would the characteristics of this inclusive, generalised international be? The domestic, in Bull's picture, is the embodiment of ordered community, where there is automatic agreement over basic goals and values. Intentions are transparent, communication unproblematic, the participants in the community present in a shared space. The international, when seen in contrast to the domestic, is an arena of conflict and disagreement over values and goals. Intentions are in doubt, communication between cultures difficult, participants in the dialogue absent. To the extent that the international can be described as an international society, it does, according to Bull, approximate to the domestic - it has shared values and norms - but, nevertheless, it will always be lacking. It will always, as argued above, be seen as incomplete and at risk, solely because it is constituted in relation to the domestic. However, if this relation with the domestic is abandoned and the domestic is seen not in opposition to the international (and superior to it) but rather as a species of a generalised international, then the picture changes. If the consensus and order that is seen to reign in the domestic is seen not as a happy twist of fate, brought about by a natural coincidence of views and values and a shared history, ${ }^{87}$ but as the effect of a form of association that minimises dissent and rewards conformity to produce an appearance of homogeneity, then our view of the world is altered. A generalised international might then appear as the realm of inevitable differences and disagreements that are occasionally concealed to create the appearance of a harmonized, uniform social order.

What might it mean to think in terms of a generalised international ${ }^{88}$ What are the implications? First, of course, the distinction between domestic and international disappears, at least in its present form. We could no longer assume it made sense to separate politics analytically into domestic politics within states and international politics between them. Instead, domestic politics would need to be seen as an unusual and historically specific form of association that takes place only when there are distinct states with borders and defined populations. One would want to understand how such formations came about, what sustained them and why, ${ }^{89}$ and what their function was politically in the larger framework of the generalised international of which they were a

\footnotetext{
${ }^{87}$ This is something Bull does not say but seems to imply.

${ }^{88}$ For an earlier discussion of the deferred questions which would be brought into view by such a move see Ashley, "The powers of anarchy". See also David Campbell's discussion of 'radical interdependence' in Politics without Principle: Sovereignty, Ethics and the Narratives of the Gulf War (Boulder, Colorado: Lynne Rienner, 1993).

${ }^{89}$ These are questions that have been addressed in sociology, and in international relations under the label 'historical sociology', but that are often seen as marginal to international politics. Examples of classic works here are Philip Corrigan and Derek Sayer, The Great Arch: English State Formation as Cultural Revolution (Oxford: Blackwell, 1985); Barrington Moore, The Social Origins of Dictatorship and Democracy: Lord and Peasant in the Making of the Modern World (Boston: Beacon Press, 1966); Karl Polanyi, The Great Transformation: The Political and Economic Origins of Our Time (Boston, MA: Beacon Press, 1944); Theda Skocpol, States and Social Revolutions: A Comparative Study of France, Russia and China (Cambridge: Cambridge University Press, 1979).
} 
part. This raises new and different questions. Restrictions on the free movement of people geographically would be something in need of explanation and justification in terms of its political and economic functions and effects, for example. The separation of the domestic as an area of sovereign control from the international would be what was in need of explanation rather than vice versa. One might explore how we have come to accept this situation as natural.

Second, the idea of homogeneous groups of people sharing common values and a common culture over time would not be taken as given: the view of domestic society as based on consensus in any case comes from particular, highly contested approaches to sociological thought. ${ }^{90}$ The expectation would be that individual subjects were produced by a series of loyalties, none of them necessarily pure. Communities might be spread around the globe, with people's subjectivities invariably hybrid, ambiguous and fluctuating. Claims to purity, whether racial or cultural, would be in need of study and explanation. ${ }^{91}$ Coalitions of support and political advocacy would be seen as constituted, temporary and issue-based.

Generalising the international or thinking in terms of the 'international in general' clearly affects the questions raised by the events of September $11^{\text {th }}$ in relation to security. The considered response at the time was a reformulation around the National Strategy for Homeland Security. As we have seen, the dilemma that seems to be at the heart of this strategy is the supposed trade off between the desire "to ensure the security of our people and preserve our democratic way of life" and the belief that this very way of life constitutes inevitably a "source of inherent vulnerability". 92 Security in this setting remains ever elusive. No sooner is one type of target protected than the terrorists,

\footnotetext{
${ }^{90}$ Views of the social order as based on consensus are derived from a Durkheimian approach, particularly that found in the work of American sociologist Talcott Parsons. This is challenged by more recent sociology, including that drawing on Marxist and Weberian analyses of the social, which sees it as comprising groups with different interests and based more on conflict than on consensus. See, for example, the discussion in Dennis H. Wrong, "The Oversocialised Conception of Man in Modern Sociology", American Sociological Review, 26(2) April 1961, pp. 183-193 (Reprinted in Robert Bocock et al (eds.), An Introduction to Sociology (London: Fontana, 1980), pp. 23-51).

${ }^{91}$ Again, these questions have been addressed in postcolonial politics, in the work for example of Homi Bhabha, Edward Said, Gayatri Spivak, Frantz Fanon, and by a number of critical scholars in international relations (See, for example, Homi Bhabha, The Location of Culture (London: Routledge, 1994); David Campbell, National Deconstruction: Violence, Identity and Justice in Bosnia (Minneapolis, MN: University of Minnesota Press, 1998); James Clifford, Routes: Travel and Translation in the Late Twentieth Century (Cambridge, MA: Harvard, 1997); Roxanne Lynn Doty, Imperial Encounters: The Politics of Representation in North-South Relations (Minneapolis: University of Minnesota Press, 1996); Frantz Fanon, Black Skin, White Masks (London: Pluto, 1986); Stuart Hall, "The Local and the Global: Globalization and Ethnicity", in Anne McClintock, Aamir Mufti and Ella Shohat (eds.), Dangerous Liaisons: Gender, Nation and Postcolonial Perspectives (Minneapolis: University of Minnesota Press, 1997), pp. 173-87; Kathryn A. Manzo, Creating Boundaries : The Politics of Race and Nation (Boulder, Colorado: Lynne Rienner, 1996); Edward Said, Culture and Imperialism (Harmondsworth: Penguin, 1993); Michael J.Shapiro, and Hayward R. Alker (eds.), Challenging Boundaries: Global Flows, Territorial Identities (Minneapolis: University of Minnesota Press, 1996); Gayatri Chakravorty Spivak, A Critique of Postcolonial Reason: Toward a History of the Vanishing Present (Cambridge, MA: Harvard, 1999).

${ }^{92}$ Homeland Security, p. 7.
} 
"lurking in the shadows," 93 move to another. Thus, the provision of security is a "formidable challenge" 94 but one that must be mastered. Security must be provided. The generalised international, in contrast, would be a realm in which the provision of security was recognised as a political decision once again. The costs of the provision of security for one person at the expense of increased insecurity for another would need to be considered and debated.

Derrida has noted the aporia of "how to decide between, on the one hand, the positive and salutary role played by the 'state' form ... in providing protection against certain kinds of international violence (the market, the concentration of world capital, as well as 'terrorist' violence and the proliferation of weapons) and, on the other hand, the negative or limiting effects of a state ... that closes its borders to non-citizens, monopolises violence ... The state is both self-protecting and self-destroying, at once remedy and poison." "95 He has suggested two possibilities: first a "new International"96 and second "democracy to come." The "new International" is "a link of affinity, suffering and hope," similar to the Marxist International, and one that is "International before, across and beyond any national determination." "It is "an alliance without institution" among those who hold to a certain spirit of Marxism that is open to "interminable self-critique," 99 not a workers' international but a "critique of the state of international law, the concepts of State and nation, and so forth." ${ }^{100}$ What he calls democracy to come "would go beyond the limits of cosmopolitanism, that is, of world citizenship. It would be more in line with what lets singular beings (anyone) 'live together', there where they are not yet defined by ... their condition as...legitimate members of a nation-state or even of a confederation or world state." 101 It would require "another thought and another putting into practice of the concept of the 'political' and the concept 'world'.,"102 The latter is what we are suggesting with our concept of the generalised international.

In The Anarchical Society, Bull opts for presence, in the form of order and security. The generalised international implies the acceptance of a generalised absence. But although throughout the book Bull opts for order at the expense of justice and change or uncertainty, in the conclusion the uncertainty that has haunted the book resurfaces. Bull insists, in a way surprisingly reminiscent of Derrida, that the book should not be read as offering a series of prescriptions: "the search for conclusions that can be presented as 'solutions' or 'practical advice' is a corrupting element in the contemporary study of

\footnotetext{
${ }^{93}$ Homeland Security, p. vii.

${ }^{94}$ Homeland Security, p. 29.

${ }^{95}$ Jacques Derrida, “Autoimmunity: Real and Symbolic Suicides”, in Giovanna Borradori (ed.), Philosophy in a Time of Terror: Dialogues with Jurgen Habermas and Jacques Derrida (Chicago: University of Chicago Press, 2003), p. 124.

${ }^{96}$ Jacques Derrida, Specters of Marx: The State of the Debt, the Work of Mourning, and the New International trans.lated by Peggy Kamuf, Bernd Magnus and Stephen Cullenberg (eds.), (New York: Routledge, 1994).

${ }^{97}$ Jacques Derrida, Politics of Friendship, translated by George Collins (London: Verso, 1997).

${ }^{98}$ Derrida, Specters of Marx, p. 85.

${ }^{99}$ Derrida, Specters of Marx, p. 89.

${ }^{100}$ Derrida, Specters of Marx, p. 86.

${ }^{101}$ Derrida, "Autoimmunity”, p. 130.

${ }^{102}$ Derrida, “Autoimmunity”, p. 130.
} 
world politics... Such conclusions are advanced less because there is any solid basis for them than because there is a demand for them which it is profitable to satisfy." 103 Although, as he admits, the argument has been that order in world politics is produced in international society and through its rules and institutions, he argues that this is not all there is to it. First international society is only one element in world politics (others being war or conflict and what he calls "human community") and the extent to which it contributes to "order within the great society of all mankind"104 is an empirical question. Second he returns to the question that he has put to one side: justice. Order conflicts with the goals of justice, but "while there is a sense in which order is prior to justice, it does not follow that goals of order are to be given priority over goals of justice in any particular case." 105 In other words, Bull ends up arguing for politics, in the sense of particular decisions in specific practical or empirical circumstances, as against the search for predictability and order. The particular decisions always exceed what can be based on or drawn from academic prescriptions. But this is not something to be regretted, for Bull. On the contrary, we should be content to "grope about in the dark" rather than pretending "that we can see the light."

This is an extraordinary turnabout: once Bull's argument is completed, it unravels before our eyes. In his final sentences, which are cited in full in the epigraph to this paper, he calls for an openness to the future to come, in all its uncertainty and unpredictability. Politics, in the Derridean sense, is brought back in. Justice is in some cases to be prioritised over order: precisely when remains to be decided.

\section{Conclusion}

Our examination of Bull's work on order in world politics has highlighted several points in his argument. First we noted that what he regards as a 'successful' order entails intentionality and hence presence: order in social life is only to be regarded as order if it is directed towards certain goals. The problem with this is that intentions are difficult to establish, and the very notion requires the presence of a fully self-conscious agent. In addition we noted that it is exactly uncertainty over intentions and disagreement over goals that leads to social interaction in the first place. Bull does not allow for differences over the basic goals of a society (though he does recognise difference can exist at a lower level) and does not consider how those differences might be resolved: for him the state or the domestic arrives as a fully-formed (and unproblematically present) consensual space. Second we saw how for Bull order and justice have to be seen as two separate or separable facets of world politics, in order for him to set justice to one side and study order. However, it becomes clear that order is in fact necessary for justice: the two are not separable in this way - one is haunted by the other. In fact justice for Bull is a supplement to order. Moreover, there is a sense in which Bull values order more highly than justice. In part this is because he regards justice as subjective. We have shown however, that order, with its relation to purpose, is also 'subjective'. Finally we argued that Bull is 'domesticating the international': using notions of order thought through in the domestic context, seen as unproblematic, to talk about what order might be in the

\footnotetext{
${ }^{103}$ Bull, Anarchical Society, p. 308.

${ }^{104}$ Bull, Anarchical Society, p. 308.

${ }^{105}$ Bull, Anarchical Society, p. 308.
} 
international. The international can be ordered to the extent that it constitutes a 'society', or, in other words, to the extent that it imitates the domestic.

By defining 'order' in terms of presence and certainty, and setting aside 'justice' to focus on 'order', Bull is setting aside politics. Politics takes place when order, in the form of rules or a legal system, fails us. It is characterised by a process of decisioning marked by uncertainty. Bull is not alone in making this depoliticising move; many other writers in international relations rely on a separation of the international, as a realm of disorder, and the domestic. Indeed as mentioned in the introduction, this move is one that enables the discipline of international relations to constitute itself as a discipline. The same move is made by the US administration in response to September $11^{\text {th }}$. The events of that day are constituted as an attack on US domestic space from outside - the dangerous international is intruding into the peaceful domestic.

What we are proposing is a recognition of the contingency of present political forms and the discourses that we use to produce and describe them. Rather than either starting from a world that is already divided into two spheres - the international and the domestic —or trying to extend the apparent consensus and security of the domestic to the international — inevitably an imperial imposition — what we are suggesting is thinking that starts from a generalised international. Such thinking, we would like to suggest, may provide the possibility of an openness to alternative ways of thinking about what should be done in world politics - in other words, an openness to politics itself. We would want to argue, with Derrida and with Bull, that any temptation to set out a programme or to recommend certain policy options in the abstract must be avoided. At the moment, actions are limited by the ways in which the world is thought: the distinction between the international and the domestic makes it possible for irresponsibility to masquerade as responsibility. Attacks on those outside the domestic sphere can be justified on the grounds of security for those within it. Essentialist identities are put in place that allow ontological claims to replace the epistemological critique Buck-Morss calls for. We can forget our common vulnerability in the search for an illusion of security. The call for politics and responsibility entails an openness to the future that refuses to try to predict or recommend what that future should be. This does not lead to passivity, however, but rather to action and ethico-political responsibility in the here and now. In a sense, the future is not the future but the present. It is now that responsibility, if there is such a thing, takes place. We cannot see the future-if we attempt to do so we rule out the possibility of a future that is completely other to what we can imagine. This general uncertainty is what we have called the generalised international: a sphere where security and order are not the ultimate aim, but where complexity and diversity are acknowledged and dealt with politically, not obliterated. It is better, as Bull recommends, to "grope about in the dark;" at least in that way we retain an openness to the future to come and to politics. 